\title{
The Effects of Differential Learning Method on the Tennis Ground Stroke Accuracy and Mobility
}

\author{
Yahya Yildırım $^{1} \&$ Ali Kizılet ${ }^{2}$ \\ ${ }^{1}$ Department of Common Courses, Bursa Technical University, Bursa, Turkey \\ ${ }^{2}$ Faculty of Sport Sciences, Marmara University, Istanbul, Turkey \\ Correspondence: Yahya Yıldırım, Department of Common Courses, Bursa Technical University, Bursa, Turkey. \\ E-mail: yahya.yildirim@btu.edu.tr
}

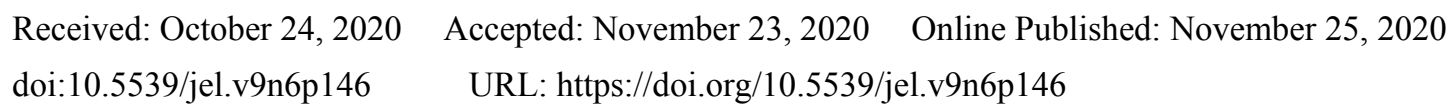

\begin{abstract}
The purpose of this study is to investigate the effect of different learning methods on learning tennis stroke skills, retention of learned skills and mobility time compared to traditional learning methods. Twenty-four (12 boys, 12 girls) high school students who have just started tennis education in a high school in Istanbul participated in this study voluntarily (Age: $15.00 \pm 0.00$ years, weight: $63.46 \pm 10.64 \mathrm{~kg}$, height: $1.65 \pm 0.06 \mathrm{~m}$, and body mass index $23.26 \pm 2.91 \mathrm{~kg} / \mathrm{m}^{2}$ ). Subjects were divided into two homogeneous groups of 12 , each with equal numbers of boys ( 6 girls, 6 boys) according to the pre-test results. One of the groups was named control group, and the other group was named differential learning group. The training sessions were held 3 days a week for 10 weeks and each training lasted 90 minutes. The International Tennis Number (ITN) test was applied to determine the tennis ground stroke accuracy and mobility time. A modified version of the ITN mobility test was applied using the Fitlight TrainerTM device. Repeated Measures Anova test was used to examine the difference between pre-test, post-test and retention test of the same group. One Way Anova was used for the interaction between groups, measurement (pre-test, post-test, retention test) means. $\mathrm{p}<0.05$ was accepted for the significance level in the interpretation of statistical procedures. As a consequence; It can be said that the differential learning method is more effective than traditional training methods in the accuracy of tennis ground hits, but there is no significant difference between the two groups in retention of learning. Moreover, no significant difference was found in mean differences between groups and from pre-test to post-test and retention test within groups.
\end{abstract}

Keywords: tennis, traditional learning, differential learning, stroke accuracy, mobility

\section{Introduction}

Although the number of scientific studies focusing on the most suitable teaching methods to improve sportive performance has increased in recent years, it is still not sufficient (Rivera \& Badillo, 2019). Especially in sports where balls, rackets and similar tools are used, it is more difficult to repeat the techniques in the desired quality because many different situations are encountered during the application of techniques in these sports branches. Because of this reason, in order for the techniques learned to be applicable during the competition, the teaching methods and techniques should include diversity (Frank et al., 2008).

Studies in many sports have shown that different exercises increase skill learning rates more than repetitive exercises (Hegen \& Schöllhorn, 2012; Humpert \& Schöllhorn, 2006; Lattwein et al., 2014; Beckmann et al., 2010). In addition, the body should be exposed to some physiological changes and differences during exercise to ensure the long-term permanence of learning (Boström et al., 2013; Alleman et al., 2015).

Tennis, where the number of participants is rapidly increasing today, is a versatile sport where technical skills are the dominant factor for a good performance, but also requires tactical, psychological and high level of physical ability (Reid \& Schneiker, 2008; Fett et al., 2017). Success in this sport depends on the combination of accuracy, speed and mobility from different angles. Depending on the new training approaches applied in the development of these physical characteristics, the game has become to be played at a higher speed (Fernandez et al., 2013).

In tennis, the players must be at the right point of the field at the right time to make an effective hit. Therefore, mobility and speed are very important (Ferrauti et al., 2002). The mobility is defined as the ability of athletes to 
adapt to different conditions, to react suddenly, to correct their body positions as required, and to transition between skills in the most efficient way possible (Brown \& Ferrigno, 2005; Ratamess, 2012). As can be understood from this definition, the concept of mobility is one of the prerequisites for the effective display of skills. One of the important components of physical fitness, mobility should be carefully included in the training process (Paul et al., 2011).

Meeting the versatile requirements for both physical and technical characteristics in tennis are key factors for an effective performance. Using scientific and innovative methods has become very important for athletes to achieve success. One of them is the differential learning method (Schöllhorn, 2000). The differential learning method is based on the principles of random tools and equipment to confuse the mind in the skill learning process, mounting the ground and body movements on the skill, and avoiding corrective feedback by avoiding excessive repetition during the training process (Schöllhorn et al., 2012). The results obtained with the differential learning method are as successful as traditional methods. In addition, it is seen that the rates of learning are much higher with different learning approaches (Müller et al., 2009).

The purpose of the present study is to investigate the effect of differential learning method on tennis ground stroke accuracy, the retention of the mobility time and learned skills, in comparison with the traditional methods. The basic hypothesis of this study is that the DL method will have a positive effect on tennis ground stroke accuracy, the retention of the learned and mobility time.

\section{Methods}

\subsection{Participants}

Twenty-four (12 female, 12 male) students who attended a high school tennis training course in Istanbul participated in the study voluntarily. Subjects were divided into two homogeneous groups of 12, each with equal numbers of boys ( 6 girls, 6 boys) according to the results of the pre-test. One group formed the differential learning group (DLG) and the other the control group (CG). The demographic and physical characteristics of the participants are given in Table 1. Participants' height was measured with a $0.1 \mathrm{~cm}$ precision stadiometer, body weight with thin clothes and bare feet with a digital display scale with a precision of $0.1 \mathrm{~kg}$ (Sanz et al., 2019).

Written informed consent of the subjects about the study was obtained from the families and the school administration. In addition, the approvals of the subjects were received and the voluntary consent form prepared in accordance with the Declaration of Helsinki was filled. All procedures were approved by the Marmara University Institute of Health Sciences Ethics Committee (Date: 02.04.2018, document number: 126).

Table 1. Descriptive statistics by group (mean $\pm \mathrm{SD}$ ).

\begin{tabular}{lllll}
\hline Group & Age (years) & Body height $(\mathrm{m})$ & Body mass $(\mathrm{kg})$ & BMI $(\mathrm{kg} / \mathrm{m} 2)$ \\
\hline DLG $(\mathrm{n}=12)$ & $15.00 \pm 0.00$ & $1.66 \pm 0.06$ & $62.72 \pm 11.68$ & $22.60 \pm 3.06$ \\
CG $(\mathrm{n}=12)$ & $15.00 \pm 0.00$ & $1.64 \pm 0.05$ & $64.20 \pm 9.96$ & $23.90 \pm 2.72$ \\
Total $(\mathrm{n}=24)$ & $15.00 \pm 0.00$ & $1.65 \pm 0.06$ & $63.46 \pm 10.64$ & $23.26 \pm 2.91$ \\
\hline
\end{tabular}

Note. DLG $=$ Differential Learning Group; $\mathrm{CG}=$ Control Group; BMI = Body Mass Index.

\subsection{Measures and Procedures}

In both groups, 90-minute training sessions were applied 3 days a week for 10 weeks. After warming up in the training, one group (DLG) received tennis training with the differential learning method, while the other group (CG) was trained using traditional tennis teaching methods. Based on the differentiation principles of Schöllhorn in DL, it is based on the assembly of random tools, grounds and movements to unsettle the mind, avoiding repetition in the same pattern and avoiding corrective feedback during the application process (Schöllhorn, 1999). In the control group, a standard training program based on repetition and frequent corrective feedback was applied. At the end of the training, both groups cooled in the same content and time.

\subsection{Differentiation Principles in Differential Learning (Schöllhorn, 1999)}

\section{Different body movements}

- Bending the body forward/backward before strike

- Don't put the reverse foot forward before the hit

- Extending arms in different directions before beating

- Kicks on one leg 
- Kneeling/sitting kicks

- One turn on your own axis after the hits

- Double foot leaping up during the stroke

- The racket goes in different directions instead of following the ball after the hit

\section{Perceptual differences}

- One-eye closed strokes

- Racket grips with thick gloves

- Stand back turned ball

- Beats with earplugs

- Kicks on the balance board and bosu ball

\section{Different vehicle/equipment and floor}

- Different rackets (stick, funnel, soccer ball)

- Different balls (elastic ball, crazy ball, table tennis ball and creased paper)

- Different floor (cobblestone, gym mat)

The tests were applied on the standard tennis court (hard ground) at the weekend. In the last 24 hours before the tests, the athletes had no other strenuous physical activity and in the last 3 hours they did not consume any drink or food other than water. All measurements and tests were made on the same day and 13-15 minutes of warm-up and stretching were made before the tests. The tests were applied three times as a pre-test at the beginning of the study, a post-test at the end of the ten-week training period, and a retention test two weeks after the end of the study.

\section{Tennis Strokes Test}

Ground stroke accuracy was measured and scored using the forehand backhand accuracy test portion of the International Tennis Number (ITN) test. ITN is an application started to be implemented by the International Tennis Federation (ITF) to determine the game levels of tennis players in the world (International Tennis Federation, 2004).

The execution of the test is shown in Figure 1, P shows the places where the player will stop, and $\mathrm{F}$ the trainer who will feed the ball. The coach (F) throws 6 balls to the forehand side and one backhand side alternately towards the place indicated by the letters " $\mathrm{xx}$ " in front of the player $(\mathrm{P})$, the player hits these balls in parallel, then the coach (F) gives the player (P), throws 6 more balls to a forehand side and a backhand side, alternating towards the places indicated by the letters " $\mathrm{xx}$ " in front, the participant throws these balls towards the cross.

- 0 points if the ball goes out or gets caught in the net;

- 1,2 or 3 points depending on the first contact,

- According to the second contact;

i. 0 points if he falls on the field,

ii. +1 extra point if the force field falls into the +1 point zone,

iii. If the strength field falls into the area with double points, the score will be multiplied by 2 .

- In addition, 1 extra point is added for each ball that falls inside (http://www.tennisplayandstay.com/itn/itn-assessment.aspx, Accessed on: 17.11.2020). 


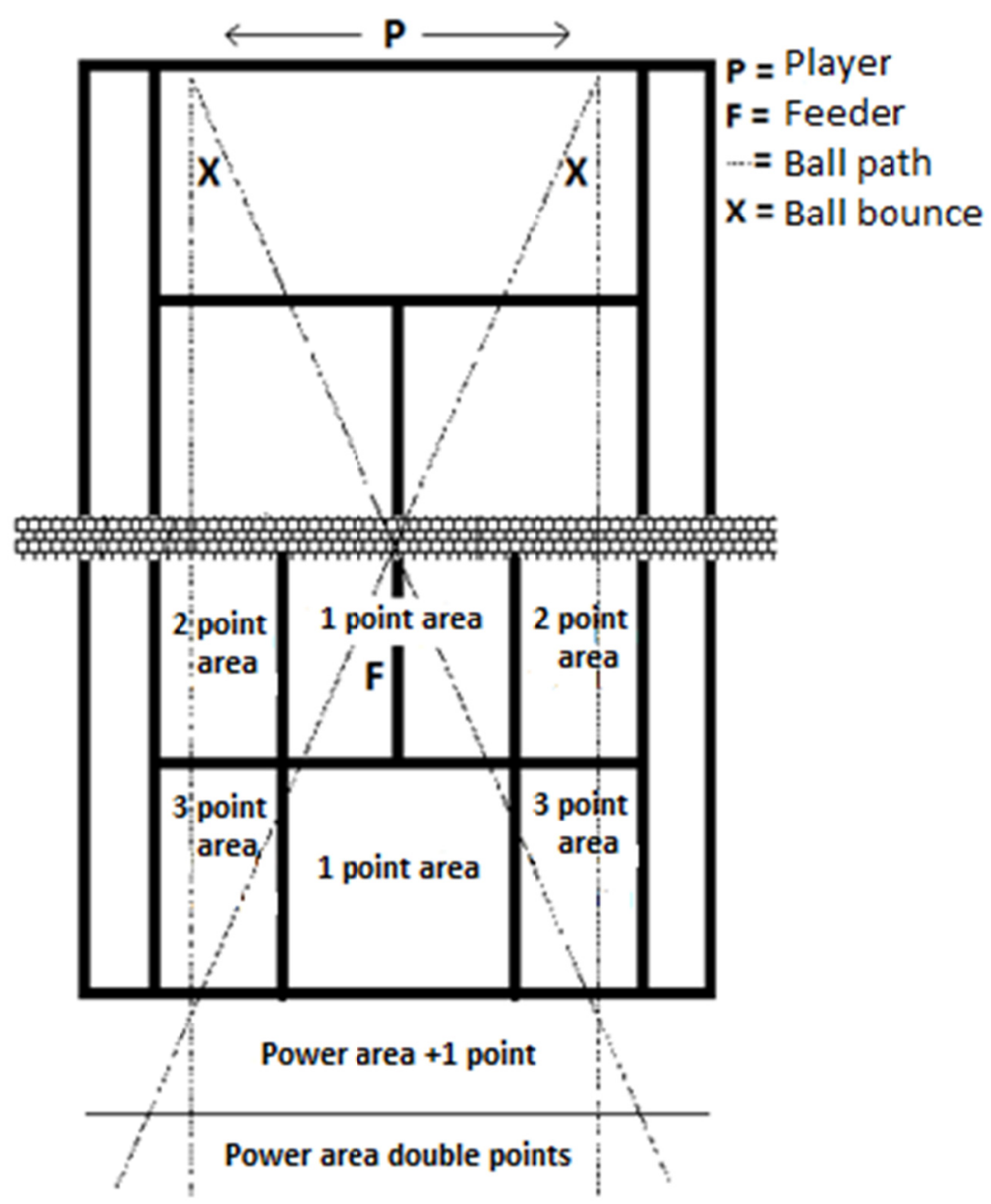

Figure 1. Tennis ground stroke accuracy test (Gürel, 2013)

\section{Mobility Test}

A modified version of the ITN mobility test with the Fitlight TraineTM device was applied to measure tennis-specific mobility (Figure 2). The locations of the Fitlight TrainerTM lights in the mobility test are as shown in the figure on a standard tennis court. Start is made from the middle of the back line, each light turns on in the following order and is turned off by contact with the hand; $1-2-1-3-1-4-1-5-1-6-1$. The duration starts with the turning off the light number 1 and after each light is turned off, the 1st light comes on again, when the last light number 1 is touched, the time stops and the result is in seconds (Yildırım et al., 2020). 


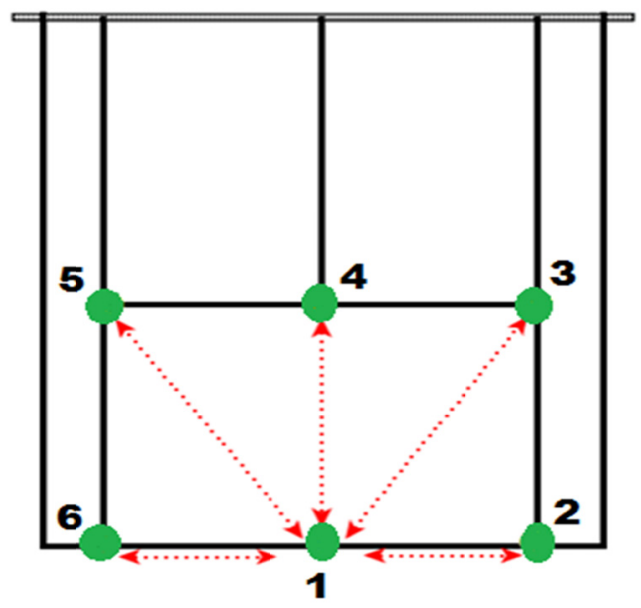

Figure 2. International tennis number mobility test (Yıldırım et al., 2020)

\section{Statistical Analysis}

SPSS 16.0 package program was used for data analysis (SPSS Inc., Chicago, IL, USA). Repeated Measures Anova test was used to examine the difference between pre-test, post-test and retention test of the same group. One Way Anova was used for the interaction between groups (experimental and control), measurement (pre-test, post-test, retention test) means. $\mathrm{p}<0.05$ was accepted for the significance level in the interpretation of statistical procedures.

\section{Results}

As a result of the pre-test performed at the beginning of the study, there was no statistically significant difference between the groups in the mean ground stroke accuracy scores $(F=0.213, p=0.649>0.05)$. As a result of the post test and retention test, it was seen that there was a statistically significant difference between two groups ( $\mathrm{F}$ $=6.933, \mathrm{p}=0.015<0.05 ; \mathrm{F}=5.107, \mathrm{p}=0.034<0.05$, respectively). Considering the situation within the groups as a result of the repeated tests; It was seen that there was a statistically significant increase $(p=0.000<0.05)$ in the mean scores of two groups ground stroke accuracy from pre-test to post-test. With a significant increase from pre-test to post-test in both groups, the DLG increase percentage value was nearly twice as high $(122.59 \%$ and $70.35 \%$, respectively). It was observed that there was no significant change between the posttest-retention test in both groups $(\mathrm{p}=0.582>0.05 ; \mathrm{p}=0.880>0.05$, respectively) (Table 2$)$.

In the study, no statistically significant difference was found between the two groups in terms of pre - post test and retention test results in the mean mobility time (respectively; $\mathrm{F}=0.51, \mathrm{p}=0.485>0.05 ; \mathrm{F}=1.08, \mathrm{p}=0.309>$ $0.05 ; \mathrm{F}=0.18, \mathrm{p}=0.674>0.05$, respectively). Considering the situation within the groups as a result of the repeated tests; It was observed that there were irregular decreases and increases in the mean mobility times of both groups from pre-test to post-test and from post-test to retention test, but these changes were not statistically significant $(\mathrm{p}>0.05)$ (Table 3).

Table 2. The results of the one-way anova and the repeated measures anova of the ground storke accuracy pre-test, post-test and retention-test scores of DLG and CG athletes and change scores

\begin{tabular}{|c|c|c|c|c|c|c|c|}
\hline \multirow[t]{2}{*}{ Group } & & \multirow{2}{*}{$\begin{array}{l}\text { Pre-test (1) } \\
\text { Mean (Points) }\end{array}$} & \multirow{2}{*}{$\begin{array}{l}\text { Post-test (2) } \\
\text { Mean (Points) }\end{array}$} & \multirow{2}{*}{$\begin{array}{l}\text { Retention-test (3) } \\
\text { Mean (Points) }\end{array}$} & \multicolumn{3}{|c|}{ Repeated Measures Anova } \\
\hline & & & & & Test & Mean Differences \% & Sig. ${ }^{b}$ \\
\hline \multirow[t]{3}{*}{$\operatorname{DLG}(\mathrm{n}=12)$} & & $11.42 \pm 5.26$ & $25.42 \pm 8.72$ & $26.75 \pm 8.89$ & $1-2$ & $-122.59^{*}$ & 0.000 \\
\hline & & & & & $2-3$ & -5.23 & 0.582 \\
\hline & & & & & $1-3$ & $-134.24^{*}$ & 0.000 \\
\hline \multirow[t]{3}{*}{$\mathrm{CG}(\mathrm{n}=12)$} & & $10.42 \pm 5.35$ & $17.75 \pm 5.07$ & $19.08 \pm 7.68$ & $1-2$ & $-70.35^{*}$ & 0.000 \\
\hline & & & & & $2-3$ & -7.49 & 0.880 \\
\hline & & & & & $1-3$ & $-83.11^{*}$ & 0.001 \\
\hline \multirow[t]{2}{*}{ One Way Anova } & $\mathrm{F}$ & 0.213 & 6.933 & 5.107 & & & \\
\hline & $\mathrm{p}$ & 0.649 & $0.015^{*}$ & $0.034^{*}$ & & & \\
\hline
\end{tabular}

Note. ${ }^{*}$ Significant difference $(\mathrm{p}<0.05)$. 
Table 3. The results of the one way anova and the repeated measures anova of the mobility pre-test, post-test and retention-test scores of DLG and CG athletes and change scores

\begin{tabular}{|c|c|c|c|c|c|c|c|}
\hline \multirow[t]{2}{*}{ Group } & & \multirow{2}{*}{$\begin{array}{l}\text { Pre-test (1) } \\
\text { Mean (Second) }\end{array}$} & \multirow{2}{*}{$\begin{array}{l}\text { Post-test (2) } \\
\text { Mean (Second) }\end{array}$} & \multirow{2}{*}{$\begin{array}{l}\text { Retention-test (3) } \\
\text { Mean (Second) }\end{array}$} & \multicolumn{3}{|c|}{ Repeated Measures Anova } \\
\hline & & & & & Test & Mean Differences \% & Sig. ${ }^{b}$ \\
\hline \multirow{3}{*}{\multicolumn{2}{|c|}{$\operatorname{DLG}(\mathrm{n}=12)$}} & $20.42 \pm 2.02$ & $20.08 \pm 1.78$ & $20.84 \pm 1.75$ & $1-2$ & 1.67 & 1.000 \\
\hline & & & & & $2-3$ & -3.78 & 0.080 \\
\hline & & & & & $1-3$ & -2.06 & 0.943 \\
\hline \multirow{3}{*}{\multicolumn{2}{|c|}{$\mathrm{CG}(\mathrm{n}=12)$}} & $21.00 \pm 2.00$ & $20.83 \pm 1.75$ & $21.15 \pm 1.80$ & $1-2$ & 0.81 & 0.997 \\
\hline & & & & & $2-3$ & -1.54 & 1.000 \\
\hline & & & & & $1-3$ & -0.71 & 1.000 \\
\hline \multirow[t]{2}{*}{ One Way Anova } & $\mathrm{F}$ & 0.51 & 1.08 & 0.18 & & & \\
\hline & $\mathrm{p}$ & 0.485 & 0.309 & 0.674 & & & \\
\hline
\end{tabular}

Note. ${ }^{*}$ Significant difference $(\mathrm{p}<0.05)$.

\section{Discussion and Conclusion}

In recent years, the importance of innovative teaching methods related to skill learning and retention of learned in sports and the research on the subject has been increasing (Velicka et al., 2016). Studies have shown that variable application approaches increase motor learning rates and permanence more than repetitive learning approaches (Henz et al., 2018; Lage et al., 2015).

In this study; in contrast to traditional teaching methods, it was aimed to examine the effects of DL method in teaching tennis stroke skills, retention of learned skills and improvement of mobility time. The hypothesis of our study is that the DL method will have positive effects on tennis stroke skills, mobility time and retention. The results we encountered support the first part of our hypothesis. With a significant increase in ground stroke accuracy score averages in both groups, DLG increased significantly more than CG in post-tests. In a study about football shooting skills, it was observed that the DL method was more effective than the traditional learning method (Hegen \& Schöllhorn, 2012). In another research, it was seen that the differential learning method was a more effective than the traditional teaching method in those who are new to speed skating (Savelsbergh et al., 2010). In many other studies on the subject, it was observed that DL method was more effective than traditional methods in learning and retention (Henz \& Schöllhorn, 2016; Hegen et al., 2016).

In this study, there was no significant difference between the two groups in the evaluation of the mobility time. Considering that mobility is a complex structure, it can be said that a 10-week study period is not sufficient. In a study about the effect of teaching method with difference on mobility time, it was stated that there was a small increase, although it was not statistically significant (Poureghali et al., 2019).

Considering the study presented in terms of the retention of the learned skills, it was observed that there was no significant change in the ground stroke accuracy points in the period from the last test to the retention test in both groups. Therefore, it can be said that the skills learned in both groups are permanent. In a study where permanence evaluations were made, it was seen that the traditional learning group fell back to the initial level, and the DL group maintained its level, unlike our results (Hegen et al., 2016). In another research, the DL group showed superiority in maintaining post-test performance compared to the traditional teaching group (Schöllhorn et al., 2012). In a study on teaching tennis stroke techniques and retention, it was observed that a significant improvement was made in both differential and traditional learning groups from pre-test to post-test, but there was a significant decrease in the traditional group in the retention test, while the DL group remained stable (Hegen et al., 2016). While these studies show parallelism with our study in terms of the realization of learning, they differ from our study in terms of retention. In another study, it was reported that the technique progressed with a clear advantage in the learning group with differences, unlike the groups in which traditional teaching methods were used, but they were close to each other in post-test permanence (Schöllhorn et al., 2012). This study parallels our study in terms of the retention of what has been learned.

The results of this study are in line with many studies in the literature. In many studies, it has been revealed that the DL method is much more beneficial than traditional learning methods (Schöllhorn et al., 2006; Beckmann \& Schöllhorn, 2003; Henz \& Schöllhorn, 2016). According to the traditional learning approach; A large number of repetitions are considered a necessity to achieve mastery, and it is assumed that the "ideal technique" defined by world-class athletes will be developed by repeating as often as possible (Schöllhorn, 2000). When we look at the results of this study together with the studies in the literature, we think that the traditional teaching approach should be reviewed. 
In conclusion, our study in skill learning levels shows that the DL group has improved more than the traditional learning group. In addition, many studies in the literature on learning with difference have obtained more successful results than traditional methods, and it has been observed that the learning with difference method is effective for both senior athletes and beginners (Savelsbergh et al., 2010; Schöllhorn et al., 2012). Another advantage of differential is; apart from the nature of the movement, it is possible to create a new skill application model because of the new experiments in different conditions (Torrents et al., 2007). In addition, we think that it may be beneficial to use these two methods together by adding teaching practices to traditional education programs. It is thought that boredom can be prevented in athletes because there are not too many repetitions and corrective feedbacks in the same pattern in teaching with differences.

\section{Acknowledgements}

This study has been supported by Marmara University Scientific Research Projects Coordination Unit under grant number "SAG-C-DRP-110718-0438".

\section{References}

Alleman, R. J., Stewart, L. M., Tsang, A. M., \& Brown, D. A. (2015). Why does exercise "trigger" adaptive protective responses in the heart? Dose Response, 13(1), 1-19. https://doi.org/10.2203/dose-response.14-023.Alleman

Beckmann, H., \& Schöllhorn, W. I. (2003). Differential learning in shot put. In W. Schöllhorn, C. Bohn, J. Jäger, H. Schaper \& M. Alichmann (Eds.), Mechanics, Physiology, Psychology (p. 68). First European Workshop on Movement Science. Köln, Sport Buch Strauß.

Beckmann, H., Winkel, C., \& Schöllhorn, W. I. (2010). Optimal range of variation in hockey technique training. International Journal of Sports Psychology, 41, 5-10.

Boström, P. A., Graham, E. L., Georgiadi, A., \& Ma, X. (2013). Impact of exercise on muscle and non-muscle organs. IUBMB Life, 65(10), 845-850. https://doi.org/10.1002/iub.1209

Brown, L. E., \& Ferrigno, V. A. (2005). Training for speed, agility and quickness (2nd ed., pp. 1-236). Champaign (IL): Human Kinetics.

Fernandez, J., Ellenbecker, T. S., \& Sanz-Rivas, D. (2003). Effects of a 6-week junior tennis conditioning program on serve velocity. J Sport Sci Med., 12, 232-239.

Ferrauti, A., Maier, P., \& Weber, K. (2002). Tennis Training. Aachen: Meyer and Meyer Verlag.

Fett, J., Ulbricht, A., Wiewelhove, T., \& Ferrauti, A. (2017). Athletic performance, training characteristics, and orthopedic indications in junior tennis Davis Cup players. International Journal of Sports Science \& Coaching, 12(1), 119-129. https://doi.org/10.1177/1747954116684393

Frank, T. D., Michelbrink, M., Beckmann, H., \& Schöllhorn, W. I. (2008). A quantitative dynamical systems approach to differential learning: self-organization principle and order parameter equations. Biological Cybernetics, 98, 19-31. https://doi.org/10.1007/s00422-007-0193-x

Gürel, H. (2013). Tenis Temel Teknik Öğretiminde Farkl Antrenman Metotlarının El Önü (Forehand) ve El; Arkası (Backhand) Vuruş Performanslarına Etkisi. Süleyman Demirel Üniversitesi Sağllk Bilimleri Enstitüsü. Yüksek Lisans Tezi, Isparta (Danışman: Yrd. Doç. Dr. M Kumartaşl1).

Hegen, P., Rizzi, N., \& Schöllhorn, W. I. (2016). Comparison of the differential learning approach in the form of games and traditional tennis training. In A. Baca, B. Wessner, R. Diketmüller, H. Tschan, M. Hofmann, P. Kornfeind \& E. Tsolakidis (Eds.), Book of Abstract of 21st Annual Congress of the European College of Sport Science (p. 459). Wien, 6th-9th July 2016.

Hegen, P., \& Schöllhorn, W. I. (2012). Lernen an unterschieden und nicht durch wiederholungen. Fussballtraining, 3, 30-37.

Henz, D., John, A., Merz, C., \& Schöllhorn, W. I. (2018). Post-task effects on EEG brain activity differ for various differential learning and contextual interference protocols. Frontiers in Human Neuroscience, 12, 19. https://doi.org/10.3389/fnhum.2018.00019

Henz, D., \& Schöllhorw, W. I. (2016). Differential training facilitates early consolidation in motor learning. Front Behav Neurosci, 10, 199. https://doi.org/10.3389/fnbeh.2016.00199

Humpert, V., \& Schöllhorn, W. I. (2006). Vergleich von techniktrainingsansätzen zum tennisaufschlag. In A. Ferrauti \& H. Remmert (Eds.), Trainingswissenschaft im freizeitsport (pp. 121-124). Hamburg: Czwalina. 
$\begin{array}{lllll}\text { International } & \text { Tennis } & \text { Federation. } & \text { (2004). }\end{array}$ http://www.tennisplayandstay.com/media/131803/131803.pdf; accessed on 20.08.2020

Lage, G. M., Ugrinowitscha, H., Souzaa, T. A., Vieiraa, M. M., Albuquerqueb, M. R., \& Bendaa, R. N. (2015). Repetition and variation in motor practice: A review of neural correlates. Neuroscience and Biobehavioral Reviews, 57, 132-141. https://doi.org/10.1016/j.neubiorev.2015.08.012

Lattwein, M., Henz, D., \& Schöllhorn, W. I. (2014). Differential training as an intervention strategy to prevent choking under pressure in basketball freethrow. In A. De Haan, C. J. De Ruiter \& E. Tsolakidis (Eds.), Book of Abstract of the 19th Annual Congress of the European College of Sport Science (p. 610). Amsterdam, Utrecht: Digital Printing Partners, 2nd-5th July 2014.

Müller, E., Lindinger, S., \& Stöggl, T. (2009). Science and skiing IV (pp. 454-460). UK: Meyer \& Meyer Sport Ltd.

Paul, M., Biswas, S. K., Shukla, G., \& Sandhu, J. S. (2011). Effect of agility training on tennis performance. $J$ Med Sci Tennis, 16(1), 21-25.

Poureghali, S., Arede, J., Esteves, P., Schöllhorn, W. I., \& Leite, N. (2019). Differential vs conventional resistance training effects in youth basketball players. 8th International Workshop and Conference of the International Society of Performance Analysis of Spor, Technology meets Practice and Science. Budapest, Hungary, 11th-13th September.

Ratamess, N. (2012). ACSM's Foundations of Strength Training and Conditioning (pp. 39-487). China: Lippincott Williams \& Wilkins.

Reid, M., \& Schneiker, K. (2008). Strength and conditioning in tennis: current research and practice. J Sci Med Sport, 11, 248-256. https://doi.org/10.1016/j.jsams.2007.05.002

Rivera, E. L., \& Badillo, J. J. G. (2019). Comparison of the effects of three hangboard strength and endurance training programs on grip endurance in sport climbers. Journal of Human Kinetics, 66, $183-193$. https://doi.org/10.2478/hukin-2018-0057

Sanz, B., Arrieta, H., Hervas, G., Rezola-Pardo, C., Ruiz-Litago, F., Iturburu, M., ... Irazusta, J. (2019). Serum adiponectin is associated with body composition and cognitive and psychological status in older adults living in long-term nursing homes. Experimental Gerontology, 121, 1-9. https://doi.org/10.1016/j.exger.2019.03.005

Savelsbergh, G. J. P., Kamper, W. J., Rabius, J., Koning, J. J. D., \& Schöllhorn, W. (2010). A new method to learn to start in speed skating: A differencial learning approach. Int. J. Sport Psychol, 41, 415-427.

Schöllhorn, W. I. (1999). Individualität - ein vernachlässigter parameter? Leistungssport, 29(2), 7-11.

Schöllhorn, W. I. (2000). Applications of systems dynamic principles to technique and strength training. Acta Academia Olympiquae Estoniae, 8, 67-85.

Schöllhorn, W. I., Beckmann, H., Michelbrink, M., Sechelmann, M., Trockel, M., \& Davids, K. (2006). Does noise provide a basis for the unification of motor learning theories. Int J Sport Psychol, 37, 1-21.

Schöllhorn, W. I., Hegen, P., \& Davids, K. (2012). The nonlinear nature of learning-A differential learning approach. The Open Sports Sciences Journal, 5(1), 100-112. https://doi.org/10.2174/1875399X01205010100

Torrents, C., Balagué, N., Perl, J., \& Schöllhorn, W. (2007). Linear and nonlinear analysis of the traditional and differential strength training. Ugdymas Kûno Kultûra Sportas Biomedicinos Mokslai, 3(66), 39-47. https://doi.org/10.33607/bjshs.v3i66.548

Velička, D., Bernotienė, G., Poderienė, K., Vainoras, A., \& Poderys, J. (2016). Differential training tasks trigger the decrease of concatenation between cardiovascular parameters. Baltic Journal of Sport \& Health Sciences, 4(103), 38-44. https://doi.org/10.33607/bjshs.v4i103.71

Yıldırım, Y., Kızılet, A., \& Bozdoğan, T. (2020). The effect of differential learning method on the international tennis number level among young tennis player candidates. Educational Research and Reviews, 15(5), 253-260. https://doi.org/10.5897/ERR2020.3919 


\section{Copyrights}

Copyright for this article is retained by the author, with first publication rights granted to the journal.

This is an open-access article distributed under the terms and conditions of the Creative Commons Attribution license (http://creativecommons.org/licenses/by/4.0/). 